\title{
Intrahepatic Bile Duct Cancer Clinical Distant Metastasis TNM Finding v8
}

National Cancer Institute

\section{Source}

National Cancer Institute. Intrahepatic Bile Duct Cancer Clinical Distant Metastasis TNM

Finding v8. NCI Thesaurus. Code C134579.

A clinical finding about one or more characteristics of intrahepatic bile duct cancer, following the rules of the TNM AJCC v8 classification system as they pertain to distant metastases. 